\title{
Plasma concentration of tryptophan and pregnancy-induced hypertension
}

\author{
Agnieszka Grafka', Maciej topucki', Katarzyna Karwasik-Kajszczarek², Marzena Stasiak-Kosarzycka ${ }^{3}$, \\ Grzegorz Dzida ${ }^{4}$
}

\author{
'I Chair and Department of Oncological Gynaecology and Gynaecology, Medical University of Lublin, Poland \\ ${ }^{2}$ Chair and Department of Obstetrics and Pathology of Pregnancy, Medical University of Lublin, Poland \\ ${ }^{3}$ Department of Gynaecology and Obstetrics with Admission Room of the Cardinal Wyszyński Regional Specialist Hospital in Lublin, Poland \\ ${ }^{4}$ Department of Internal Diseases, Medical University of Lublin, Poland
}

\begin{abstract}
Introduction. Pregnancy-induced hypertension (PIH) is one of the main clinical problems of unexplained etiopathogenesis. New factors involved in the pathogenesis of this disease are still being searched. The available literature lacks data regarding the differences in tryptophan concentrations in physiological and PIH-complicated pregnancy. Previous studies have shown that L-tryptophan treatment reduces blood pressure in hypertensive rats. The direct vascular effects of tryptophan have not been fully explored. In this study, the stimulating effect of tryptophan on the development of PIH was revealed. The aim of the present study was to assess the differences in plasma tryptophan concentrations in physiological pregnancies and pregnancies complicated with hypertension in the third trimester. Material and methods. The study was carried on 105 complicated by PIH and 105 pregnant women with blood pressure within normal limits between 25 and 41 weeks of gestation. Tryptophan concentration was determined by the automated ion-exchange chromatography using an Amino Acid Analyser (AAA 400) by Ingos, Czech Republic. Tryptophan concentration was expressed in $\mu \mathrm{mol} / \mathrm{cm}^{3}$ plasma.

Results. The mean concentration of tryptophan in the third trimester of physiological pregnancy was found to be $0.035 \pm 0.009 \mu \mathrm{mol} / \mathrm{cm}^{3}$, whereas in PIH $-0.099 \pm 0.007 \mu \mathrm{mol} / \mathrm{cm}^{3}$.

Conclusions. The development of PIH in pregnant women is likely to be caused by increased concentrations of tryptophan, which is a substrate for production of serotonin and tryptamine. Further studies are needed to analyse the kinetics of tryptophan metabolism.

Key words: tryptophan, pregnant women, hypertension, blood plasma

Arterial Hypertens. 2018, vol. 22, no. 1, pages: 9-15

DOI: 10.5603/AH.a2017.0024
\end{abstract}

\section{Introduction}

Tryptophan is an exogenous aromatic amino acid, which undergoes multi-directional changes resulting in the formation of heterocyclic biogenic indoleamines, such as serotonin and tryptamine [1-3].

Address for correspondence: Agnieszka Grafka

I Chair and Department of Oncological Gynaecology and Gynaecology

Medical University of Lublin

Staszica 16, 20-081 Lublin, Poland

Phone: +4881 5327847 , Fax: + 48815320608 ,

E-mail: grafkaagnieszka@yahoo.com

VM Copyright @ 2018 Via Medica, ISSN 2449-6170

This study was supported by Grant of Medical University of Lublin, Poland (MNsd127).
Mediated by tryptophan 5-hydroxylase, tryptophan is converted into 5-hydroxytryptophan catabolized by decarboxylase of aromatic amino acids into 5-hydroxytryptoamine (serotonin). Serotonin stimulates the contraction of vascular smooth muscles and small bronchi, induces vasoconstriction and increases blood pressure $[1,2,4]$. It is produced in the raphe nuclei, pineal body, intestinal mucosa and thrombocytes [5]. Moreover, serotonin is a neurotransmitter stimulating the central nervous system (CNS) responsible for memory, appetite, digestion, regulation of body temperature, sleep, mood and numerous cognitive functions $[3,6,7]$. 
The human body needs about $10 \mathrm{mg}$ of tryptophan to prevent symptoms associated with its deficiency [8]. Only $1 \%$ of dietary tryptophan is metabolized to serotonin [9].

Studies in rats did not explicitly confirm the effects of tryptophan on the development of arterial hypertension. According to Lark et al. [10] and Riesselmann et al. [11], tryptophan prevented its development; Wolf et al. [12] demonstrated that the effects of tryptophan on hypertension depended on its dose. The influence of tryptophan on pregnancy-induced hypertension is still unexplained.

Tryptamine is a biogenic amine produced in the human nervous and peripheral tissues, as well as by microflora of the gastrointestinal tract; moreover, it is an ingredient of various food products. Tryptamine is involved in the development of cardiovascular diseases, such as hypertension, myocardial infarction but also migraine $[13,14]$. The serum concentration of tryptamine is correlated with the concentration of its precursor, L- tryptophan, which is metabolized to tryptamine by decarboxylase of aromatic amino acids [15]. Tryptamine has been demonstrated to constrict the rabbit aorta by direct stimulation of $\alpha$-adrenergic and 5-HT (serotonin) receptors [16]. Tryptamine-induced vasoconstriction has also been observed in the rat mesenteric arteries [17], rat tail arteries [18, 19] and rat aorta [20].

Arterial hypertension in pregnant women is one of the essential clinical problems of unknown etiopathogenesis. It can induce severe obstetric complications, such as detachment of the placenta, cerebrovascular "episodes", organ failure, eclampsia, disseminated intravascular coagulation and many others [21].

Pregnancy-induced hypertension (PIH) is one of the most serious obstetric complications. PIH can occur without proteinuria or can be associated with significant proteinuria, called preeclampsia. When intravascular haemolysis, liver damage and thrombocytopaenia occur, the HELLP syndrome develops [22, 23]. Despite intensive studies carried out in many centres worldwide, the etiopathogenesis of PIH has not been explained. The literature data reveal that PIH is underlain by impaired placental blood flow [24]. At present, the main diagnostic criterion of hypertension in pregnancy is systolic blood pressure (SBP) equal to or higher than $140 \mathrm{mmHg}$ measured at the interval of six hours or diastolic blood pressure (DBP) equal to or higher that $90 \mathrm{mmHg}$ [21-23].

\section{Objective}

The aim of the present study was to assess the differences in plasma tryptophan concentrations in physiological pregnancies and pregnancies complicated with hypertension in the third trimester.

\section{Material and methods}

\section{Patients}

The study involved 210 pregnant women, 25-41 weeks of gestation, managed in the Chair and Department of Obstetrics and Pathology of Pregnancy Medical University of Lublin and Department of Gynaecology and Obstetrics with Admission Room of the Cardinal Wyszyński Regional Specialist Hospital in Lublin in the years 2010-2014. Experimental procedures were approved by the Bioethical Commission of the Medical University of Lublin, Poland (No KE-0254/223/2010). All women accepted the study protocol and gave written informed consent for participation.

The overall number of 210 women, who participated in the study, was divided into 2 groups: study and control.

In the study group $(\mathrm{n}=105)$, elevated blood pressure ( $>140 / 90 \mathrm{mmHg}$ ) was found, yet no concomitant diseases that could increase blood pressure (e.g. diabetes) were observed. According to the recommendations of the European Society of Hypertension (ESH) and the European Society of Cardiology (ESC), blood pressure was measured twice at a 6-hour interval in a sitting position using an electronic sphygmomanometer [22, 23]. In the control group $(\mathrm{n}=105)$, blood pressure was within normal limits $(120 / 80 \mathrm{mmHg})$; women in this group did not take any drugs that could affect the cardiovascular system. To obtain detailed data, women in the study and control groups were divided into 3 subgroups: $25-34,35-38,39-41$ hbd, 35 cases each. Table I presents age, height, body weight, systolic (SBP) and diastolic (DBP) blood pressure of women participating in the study.

\section{Biochemical analyses}

The study material was venous blood collected in the fasting state from women with physiological pregnancies and pregnancies complicated with hypertension, $9 \mathrm{ml}$, to the test-tubes containing lithium heparin (aspiration-vacuum systems, Sarstedt, Germany).

Table I. Characteristics of women participated in this study

\begin{tabular}{|l|c|c|}
\hline \multirow{2}{*}{ Parameters } & \multicolumn{2}{|c|}{ Mean \pm SD } \\
\cline { 2 - 3 } & $\begin{array}{c}\text { Study group } \\
(\mathbf{n}=105)\end{array}$ & $\begin{array}{c}\text { Control group } \\
\text { ( } \mathbf{n}=105)\end{array}$ \\
\hline Age (years) & $32.11 \pm 3.91$ & $28.6 \pm 3.87$ \\
\hline Height $[\mathrm{cm}]$ & $163.01 \pm 5.3$ & $165.93 \pm 6.72$ \\
\hline Body weight $[\mathrm{kg}]$ & $96.48 \pm 7.3$ & $84.11 \pm 10.33$ \\
\hline SBP $[\mathrm{mmHg}]$ & $162.98 \pm 10.79$ & $119.54 \pm 6.76$ \\
\hline DBP $[\mathrm{mmHg}]$ & $97.67 \pm 7.01$ & $77.17 \pm 4.53$ \\
\hline
\end{tabular}


The plasma from each blood sample was collected immediately after centrifugation at $4000 \times \mathrm{g}$ for $10 \mathrm{~min}$ and then stored at $-80^{\circ} \mathrm{C}$ until analysis. For tryptophan concentration measurements, plasma was deproteinised with $6 \%$ sulphosalicylic acid in lithium - citrates buffer $(\mathrm{pH}=2.6)$ and centrifuged at $12000 \times \mathrm{g}$ for $20 \mathrm{~min}$. Tryptophan was determined by the automated ion-exchange chromatography with five lithium-citrate buffers by Moore et al. [25] using an Amino Acid Analyser (AAA 400) by Ingos, Czech Republic.

Tryptophan concentration was expressed in $\mu \mathrm{mol} /$ $\mathrm{cm}^{3}$ plasma.

\section{Statistical analysis}

Statistical analyses were performed using Statistica v. 10.0 software (StatSoft, USA).

Data were presented as a mean and standard deviation (SD). The distribution of quantitative parameters was assessed using the Shapiro-Wilk W test. All quantitative parameters were characterised by skew distribution; therefore, non-parametric tests were applied to evaluate inter-subgroup significant differences. Two independent groups were compared using the Mann-Whitney U test. Inter-quantitative parameter correlations were assessed by Spearman's rank correlation. The differences between mean values were considered as statistically significant at $\mathrm{p}<0.05$.

\section{Results}

The comparison of systolic and diastolic pressure between the control and study groups revealed significant differences. In the study group, both systolic and diastolic blood pressures were found to be higher (Fig. 1 and Fig. 2).

The mean tryptophan concentration and standard deviation in the third trimester of pregnancy were presented in Table II and Figure 3.

The mean concentration of tryptophan and standard deviation in the subgroups of the third trimester are listed in Table III.

Analysis of correlations between amino acid concentrations, systolic and diastolic pressures in hypertension-complicated pregnancies (Table IV).

\section{Discussion}

Intracellular protein distribution induces a release of free amino acids, which are precursors for synthesis of other proteins. The intracellular pool of amino

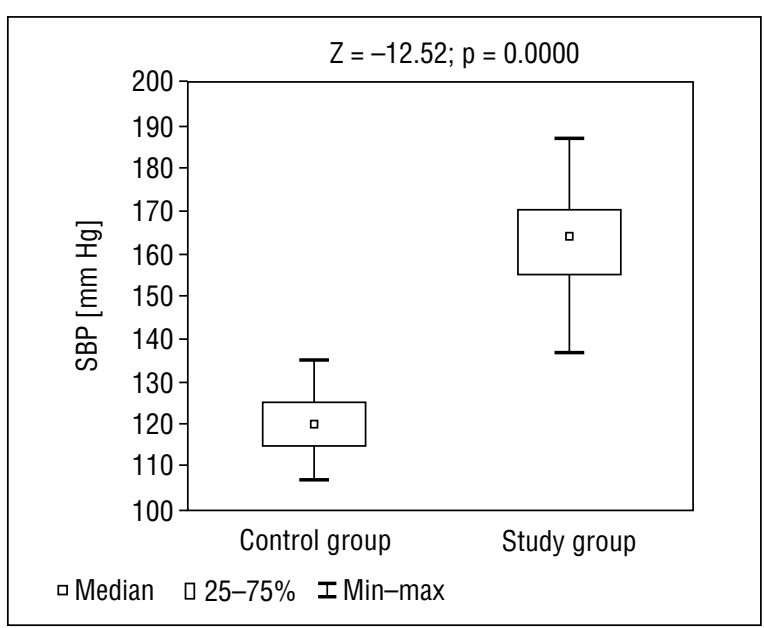

Figure 1. Differences in systolic pressures between physiological and hypertension-complicated pregnancies

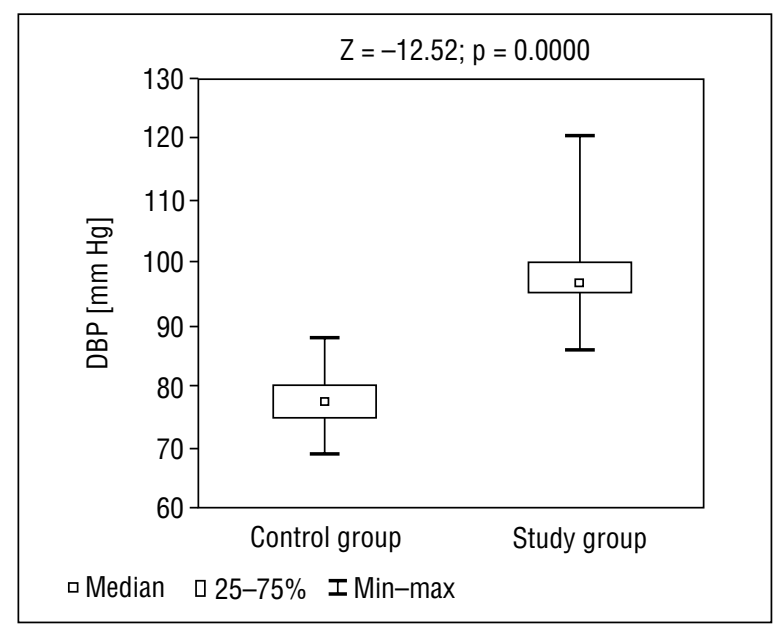

Figure 2. Differences in diastolic pressures between physiological and hypertension-complicated pregnancies

Table II. Plasma concentration of tryptophan in the control and study group with hypertension in the third trimester of pregnancy

\begin{tabular}{|l|c|c|c|}
\hline \multirow{2}{*}{ Parameter } & \multicolumn{2}{|c|}{ Mean \pm SD } & \multirow{2}{*}{$P$ value } \\
\cline { 2 - 3 } & $\begin{array}{c}\text { Study group } \\
(\mathbf{n}=105)\end{array}$ & $\begin{array}{c}\text { Control group } \\
(\mathbf{n}=105)\end{array}$ & \\
\hline TRP $\left[\mu \mathrm{mol} / \mathrm{cm}^{3}\right]$ & $0.099 \pm 0.007$ & $0.035 \pm 0.009$ & $<0.00005$ \\
\hline
\end{tabular}

acids is in balance with the extracellular pool in plasma. This balance is regulated by membranous transport characteristic of individual amino acids. Another source of extracellular pool is amino acids derived from dietary proteins [26].

Plasma tryptophan concentrations in fasting normal humans vary between 55 and $65 \mu \mathrm{mol} /$ $\mathrm{cm}^{3}$. Concentrations depend on the individual's prior protein intake (i.e., higher after diet rich in 
high-protein meals for a few days) [27], higher caloric intake [28], body mass index (lower in obesity) [29], age (lower in older men) [30] and gender (higher in males) [31]. Plasma tryptophan concentrations are readily increased by administering exogenous tryptophan. It can cause proportionate increases in brain tryptophan [32]. About $75-80 \%$ of the tryptophan in human plasma is loosely bound to albumin [33]. At first, it was anticipated that this binding would substantially retard the passage of tryptophan across the blood-brain barrier. Researchers considered measuring plasma free tryptophan (non-albumin bound), or the ratio of free tryptophan to the other large neutral amino acids, as the best predictor of brain tryptophan levels [34]. However, further studies often described treat-

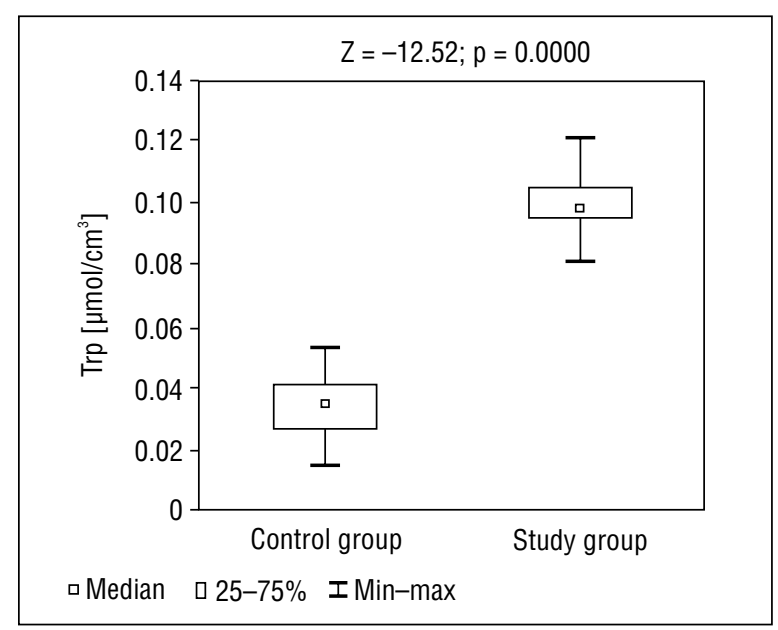

Figure 3. Concentration of TRP in the control and study group with hypertension in the third trimester of pregnancy ment-induced changes in plasma free tryptophan, which were opposite in direction to those in brain tryptophan [35].

Studies on nitrogen metabolism demonstrated that women with physiological pregnancies develop hypoaminoacidaemia, i.e. a drop in blood amino acid concentration, which maintains until delivery [26, 36-38]. The condition results from the effects of gestational hormones and increased visceral absorption of amino acids [37-41].

Pregnancies complicated with hypertension are accompanied by numerous changes, e.g. increased peripheral and placental vascular resistance, reduced plasma volume, increased reactivity of maternal vascular bed to external pressors [21, 42]. However, there are no literature data regarding changes in tryptophan concentrations.

In this study, the stimulating effect of tryptophan on the development of pregnancy-induced hypertension was revealed. In pregnancies complicated with hypertension in the third trimester, the concentration of tryptophan increased by $0.064 \mu \mathrm{mol} /$ $/ \mathrm{cm}^{3}$, compared to physiological pregnancies. Similar results were found in the individual stages of the third trimester; the increase by $0.68 \mu \mathrm{mol} / \mathrm{cm}^{3}$ was observed between 25-34 gestational week, by 0.066 $\mu \mathrm{mol} / \mathrm{cm}^{3}$ between $35-38$ week and by $0.06 \mu \mathrm{mol} /$ $/ \mathrm{cm}^{3}$ between 39-41 week. However, the correlations between tryptophan concentration and systolic and diastolic pressure separately were not confirmed. The above demonstrates that increased concentration of this amino acid in pregnant women with $\mathrm{PIH}$ is associated with a simultaneous increase in systolic and diastolic pressures.

Table III. Plasma concentration of tryptophan in women with physiological pregnancies and pregnancies complicated with hypertension in the third trimester

\begin{tabular}{|c|c|c|c|c|c|c|}
\hline \multicolumn{7}{|c|}{$\operatorname{TRP}\left[\mu \mathrm{mol} / \mathrm{cm}^{3}\right]$} \\
\hline The third & \multicolumn{2}{|c|}{$25-34$ hbd } & \multicolumn{2}{|c|}{$35-38$ hbd } & \multicolumn{2}{|c|}{ 39-41 hbd } \\
\hline Group & $\begin{array}{c}\text { Control } \\
(\mathrm{n}=35)\end{array}$ & $\begin{array}{c}\text { Study } \\
(n=35)\end{array}$ & $\begin{array}{c}\text { Control } \\
(n=35)\end{array}$ & $\begin{array}{c}\text { Study } \\
(n=35)\end{array}$ & $\begin{array}{c}\text { Control } \\
(n=35)\end{array}$ & $\begin{array}{c}\text { Study } \\
(\mathrm{n}=35)\end{array}$ \\
\hline Mean & 0.031 & 0.099 & 0.032 & 0.098 & 0.04 & 0.1 \\
\hline SD & 0.009 & 0.006 & 0.008 & 0.009 & 0.006 & 0.006 \\
\hline$P$ value & \multicolumn{2}{|c|}{$p<0.00005$} & \multicolumn{2}{|c|}{$p<0.00005$} & \multicolumn{2}{|c|}{$p<0.00005$} \\
\hline
\end{tabular}

Table IV. Correlation between plasma amino acid concentration in the study group versus systolic and diastolic pressure

\begin{tabular}{|l|c|c|c|c|c|}
\hline \multicolumn{7}{|c|}{ Group with hypertension $(\mathbf{n}=105)$} & $\mathbf{R}$ & $\mathbf{p}$ \\
\hline Trp \& SBP & $\mathbf{R}$ & $\mathbf{p}$ & & 0.139 & 0.155 \\
\hline
\end{tabular}


Amino acids are a group of compounds widely used by the human body. After their decarboxylation, biogenic amines are synthesised, i.e. factors indispensible for maintenance of cell viability and proper course of cellular processes $[2,3]$. From tryptophan, heterocyclic biogenic indoleamines are synthesized, such as serotonin and tryptamine [1-3]. Serotonin induces an increase in blood pressure by vasoconstriction and stimulation of smooth muscle constriction [1, 3, 4]. Tryptamine is responsible for the development of such cardiovascular diseases as hypertension or myocardial infarction $[13,14]$. Increased concentrations of the substrate (tryptophan) for production of the amines mentioned above are likely to result in their higher production. Once at higher concentrations, they induce more strongly an increase in blood pressure in pregnant women.

The literature lacks reports on the effects of tryptophan on the development of pregnancy-induced hypertension. The only data available regard its general impact on hypertension.

The studies by Cade et al. [43] did not confirm our results. The authors assessed the effects of tryptophan and 5-hydroxytryptophan on blood pressure in patients with slight and moderate hypertension and demonstrated that tryptophan reduced blood pressure. L-tryptophan administered in a dose of $4 \mathrm{~g} /$ day resulted in blood pressure decreases in 8 of 9 patients, whereas a dose of $800 \mathrm{mg} /$ day improved the clinical condition of 5 of 8 patients. According to the authors, no adverse side effects of the treatment were observed and serotonin was responsible for at least a part of antihypertensive effect of L-tryptophan.

Feltkamp et al. [44] demonstrated that a single dose of L-tryptophan $(50 \mathrm{mg} / \mathrm{kg}$ body weight) caused a reduction in blood pressure 90-120 minutes after administration in 14 patients with arterial hypertension yet resulted in no effects in normotensive patients. Moreover, they measured 5-HT uptake by platelets in patients not receiving L-tryptophan and did not find any differences between healthy and hypertensive patients. The administration of L-tryptophan changed the kinetics of uptake and increased 5-HT uptake in healthy individuals; in hypertensive patients, no such effects or only slight effects were noticed. Feltkamp et al. have suggested that essential hypertension central serotonergic mechanisms are involved in pathogenetic mechanisms and that the tryptophan-induced pressure-decreasing effect is caused by increased synthesis of central 5-HT.

The study by Wolf et al. [12] partially confirmed our findings. They administered L-tryptophan to rats and observed its first effects after $30 \mathrm{~min}$.; the maximum response was detected after $60 \mathrm{~min}$.
The authors found that L-tryptophan in the doses of $25-100 \mathrm{mg} / \mathrm{kg}$ body weight increased blood pressure in normotensive rats by 10 to $15 \mathrm{mmHg}$. Lower doses also increased pressure in normotensive rats while higher doses reduced blood pressure even by 30-35 mmHg. However, according to them, effects of L-tryptophan on blood pressure in normotensive and spontaneously hypertensive rats cannot be explicitly explained by L-tryptophan effects on brain serotonin.

Riesselmann et al. [11] evaluated effects of tryptophan therapeutic diet on the development of cold-induced hypertension in rats. Continuous administration of lower doses of L-tryptophan $(850 \mathrm{mg} /$ /day) prevented an increase in blood pressure, reduced hypertrophy of the heart and did not affect the body weight during exposure to cold. The use of higher doses $(1.690 \mathrm{mg} /$ day $)$ reduced the rate of blood pressure increase without affecting hypertrophy of the heart, decreased the body weight gain and increased the excretion of epinephrine with urine. Therefore, it can be stated that higher doses are likely to be associated with some toxicity. Both doses of tryptophan did not prevent the other typical symptoms developing after exposure to cold, e.g. increased weight of kidneys, adrenal glands and brown fatty tissue, increased consumption of food and water, enhanced reactions to angiotensin II or increased concentrations of aldosterone in plasma. The results of studies in rats have demonstrated that continuous administration of L-tryptophan on a diet $(850 \mathrm{mg} /$ /day) prevents the development of cold-induced hypertension.

Ardiansyah et al. [45] examined blood pressure and glucose metabolism induced by L-tryptophan in stroke-prone spontaneously hypertensive (SHRSP) rats. They demonstrated that oral administration of L-tryptophan increased blood pressure, glucose levels, insulin concentration, plasma amounts of nitric oxide and serotonin levels.

The level of serotonin (which increases after L-tryptophan) [46] is evidently associated with cardiovascular diseases and other side effects of tryptophan [47-51]. There is scientific evidence proving that serotonin formed from tryptophan results in side effects, such as vasoconstriction, that can lead to the development of hypertension [52].

Despite advances in perinatal medicine, arterial hypertension is still a serious risk for mothers and foetuses. The diagnostic procedures of pregnant women have numerous limitations. The methods using ionizing radiation, contrast or medicines are contraindicated and can be used only in life-threatening conditions [53-55]; therefore, early clinical 
markers of pregnancy-induced hypertension are being searched for whose determinations would be safe for mothers and foetuses.

Our findings suggest that tryptophan could be such a marker. However, it cannot be explicitly stated that increased tryptophan concentrations result in an increase in serotonin or tryptamine and that blood pressure increases in pregnant women in such a way. In humans, only $1-5 \%$ of tryptophan delivered to the body is converted into serotonin [56]. Further studies are needed to analyse the kinetics of tryptophan metabolism in pregnant women with PIH.

\section{Conclusions}

Early diagnosis of pregnancy-induced hypertension is a challenge to modern maternal-foetal medicine. The identification of pregnant women at increased risk of this pathology will enable prophylactic treatment before the development of the first clinical symptoms, reducing the mortality of pregnant women. Since no single factor predisposing to PIH is known, many parameters have to be analysed simultaneously.

It is to be hoped that thanks to the popularisation of studies regarding early detection of PIH and the resultant reduced costs of intensive therapy, simple, cheap and easily available PIH tests will be designed in the nearest future.

\section{References}

1. Sidransky H. Tryptophan: Biochemical and Health Implications. CRC Press 2001.

2. Berg JM, Tymoczko JL, Stryer L. Biochemistry. 5th ed. W H Freeman, New York 2002.

3. Murray RK, Bender DA, Botham KM, Kennelly PJ, Rodwell VW, Weil PA. Harper's Illustrated Biochemistry. 28th ed. Lange Medical Books/McGraw-Hill Medical Publishing Division 2012.

4. Watts SW, Morrison SF, Davis RP, et al. Serotonin and blood pressure regulation. Pharmacol Rev. 2012; 64(2): 359-388, doi: 10.1124/ pr.111.004697, indexed in Pubmed: 22407614.

5. Siegel GJ, Agranoff BW, Albers RW, Fisher SK, Uhler MD. Basic Neurochemistry, Molecular, Cellular and Medical Aspects. 6th ed. Lippincott-Raven Filadelfia, Philadelphia 1999.

6. Martí $\mathrm{O}$, Armario A. Anterior pituitary response to stress: time-related changes and adaptation. Int J Dev Neurosci. 1998; 16(3-4): 241-260, doi: 10.1016/s0736-5748(98)00030-6, indexed in Pubmed: 9785121.

7. Richard DM, Dawes MA, Mathias CW, et al. L-Tryptophan: Basic Metabolic Functions, Behavioral Research and Therapeutic Indications. Int J Tryptophan Res. 2009; 2: 45-60, doi: 10.4137/ijtr.s2129, indexed in Pubmed: 20651948.

8. Lamb S. Precursor loading for monoamines in neurological disease. J Neurosurg Nurs. 1983; 15(4): 228-233, doi: 10.1097/01376517198308000-00009, indexed in Pubmed: 6136557.

9. Jaffe R. Tryptophan Update: Helpful Adjunct and Innocent Bystander. J Nutr Med. 1994; 4(2): 133-139, doi: 10.3109/13590849409034548.

10. Lark LA, Witt PA, Becker KB, et al. Effect of dietary tryptophan on the development of hypertension in the Dahl salt-sen- sitive rat. Clin Exp Hypertens A. 1990; 12(1): 1-13, doi: 10.3109/10641969009074716, indexed in Pubmed: 2137737.

11. Riesselmann A, Baron A, Fregly MJ, et al. Effect of chronic dietary treatment with L-tryptophan on the development of cold-induced hypertension in rats. Pharmacology. 1991; 42(6): 349-360, doi: 10.1159/000138818, indexed in Pubmed: 1946599.

12. Wolf WA, Kuhn DM, et al. Pressor effects of electrical stimulation of the dorsal and median raphe nuclei in anesthetized rats. J Pharmacol Exp Ther. 1984; 230(2): 324-329, indexed in Pubmed: 6205137.

13. Eble JN. A study of the potentiation of tryptamine by monoamine oxidase inhibitors in the dog. J Pharmacol Exp Ther. 1965; 148: 48-53, indexed in Pubmed: 14279183.

14. Anwar MA, Ford WR, Herbert AA, et al. Signal transduction and modulating pathways in tryptamine-evoked vasopressor responses of the rat isolated perfused mesenteric bed. Vascul Pharmacol. 2013; 58(1-2): 140-149, doi: 10.1016/j.vph.2012.10.007, indexed in Pubmed: 23117109.

15. Wollman H, Nilsson E, Antonin KH, Bieck PR. Tryptamine kinetics in human volunteers. In: Boulton A.A., Maitre L., Beick P.R., Reiderer P. eds., Neuropsychopharmacology of Trace Amines, Clifton NJ. Humana Press, Clifton 1985: 361-378.

16. Stollak JS, Furchgott RF. Use of selective antagonists for determining the types of receptors mediating the actions of 5-hydroxytryptamine and tryptamine in the isolated rabbit aorta. J Pharmacol Exp Ther. 1983; 224(1): 215-221, indexed in Pubmed: 6129317.

17. Watts SW, Gilbert L, Webb RC. 5-Hydroxytryptamine2B receptor mediates contraction in the mesenteric artery of mineralocorticoid hypertensive rats. Hypertension. 1995; 26(6 Pt 2): 1056-1059, doi: 10.1161/01.hyp.26.6.1056, indexed in Pubmed: 7498967.

18. Hicks PE, Langer SZ. Antagonism by tetrahydro-beta-carboline of the vasoconstrictor responses to tryptamine in rat tail arteries. Eur J Pharmacol. 1983; 96(1-2): 145-149, indexed in Pubmed: 6141059.

19. Bradley PB, Humphrey PP, Williams RH. Tryptamine-induced vasoconstrictor responses in rat caudal arteries are mediated predominantly via 5-hydroxytryptamine receptors. $\mathrm{Br} \mathrm{J}$ Pharmacol. 1985; 84(4): 919-925, doi: 10.1111/j.1476-5381.1985.tb17386.x, indexed in Pubmed: 3159458.

20. Fehler M, Broadley KJ, Ford WR, et al. Identification of trace-amine-associated receptors (TAAR) in the rat aorta and their role in vasoconstriction by $\beta$-phenylethylamine. Naunyn Schmiedebergs Arch Pharmacol. 2010; 382(4): 385-398, doi: $10.1007 /$ s00210-010-0554-1, indexed in Pubmed: 20809238.

21. Magee LA, Helewa M, Moutquin M, et al. Hypertension Guideline Committee., Strategic Training Initiative in Research in the Reproductive Health Sciences (STIRRHS) Scholars., Diagnosis, evaluation, and management of the hypertensive disorders of pregnancy. J Obstet Gynaecol Can. 2008; 30(3Suppl): S1-S48.

22. Mancia G, Fagard R, Narkiewicz K, et al. Task Force Members. 2013 ESH/ESC Guidelines for the management of arterial hypertension: the Task Force for the management of arterial hypertension of the European Society of Hypertension (ESH) and of the European Society of Cardiology (ESC). J Hypertens. 2013; 31(7): 1281-1357, doi: 10.1097/01.hjh.0000431740.32696.cc, indexed in Pubmed: 23817082.

23. Magee L, Pels A, Helewa M, et al. Diagnosis, Evaluation, and Management of the Hypertensive Disorders of Pregnancy: Executive Summary. J Obstet Gynaecol Can. 2014; 36(5): 416-441, doi: 10.1016/s1701-2163(15)30588-0, indexed in Pubmed: 24927294.

24. Salmani D, Purushothaman S, Somashekara SC, et al. Study of structural changes in placenta in pregnancy-induced hypertension. J Nat Sci Biol Med. 2014; 5(2): 352-355, doi: 10.4103/09769668.136182, indexed in Pubmed: 25097413.

25. Moore S, Spackman DH, Stein WH. Chromatography of Amino Acids on Sulfonated Polystyrene Resins. An Improved System. Ana Chem. 1958; 30(7): 1185-1190, doi: 10.1021/ac60139a005.

26. Kalhan SC, Kalhan SC. Protein metabolism in pregnancy. Am J Clin Nutr. 2000; 71(5 Suppl): 1249S-55S, indexed in Pubmed: 10799398.

27. Grimes MA, Cameron JL, Fernstrom JD, et al. Diurnal variations in plasma concentrations of tryptophan, tryosine, and other neutral amino acids: effect of dietary protein intake. Am J Clin Nutr. 1979; 32(9): 1912-1922, indexed in Pubmed: 573061. 
28. Goodwin GM, Cowen PJ, Fairburn CG, et al. Plasma concentrations of tryptophan and dieting. BMJ. 1990; 300(6738): 1499-1500, doi: 10.1136/bmj.300.6738.1499, indexed in Pubmed: 2372602.

29. Caballero B, Finer N, Wurtman RJ. Plasma amino acids and insulin levels in obesity: response to carbohydrate intake and tryptophan supplements. Metabolism. 1988; 37(7): 672-676, doi: 10.1016/00260495(88)90089-3, indexed in Pubmed: 3290625.

30. Caballero B, Gleason RE, Wurtman RJ. Plasma amino acid concentrations in healthy elderly men and women. Am J Clin Nutr. 1991; 53(5): 1249-1252, indexed in Pubmed: 2021131.

31. Demling J, Langer K, Mehr MQ. Age dependence of large neutral amino acid levels in plasma. Focus on Tryptophan. Adv Exp Med Biol. 1996; 398: 579-582, doi: 10.1007/978-1-4613-0381-7_95, indexed in Pubmed: 8906329.

32. Fernstrom JD, Wurtman RJ. Brain serotonin content: physiological dependence on plasma tryptophan levels. Science. 1971; 173(3992): 149-152, doi: 10.1126/science.173.3992.149, indexed in Pubmed: 5581909.

33. McMENAMY RH, ONCLEY JL. The specific binding of L-tryptophan to serum albumin. J Biol Chem. 1958; 233(6): 1436-1447, indexed in Pubmed: 13610854.

34. Knott PJ, Curzon G. Free tryptophan in plasma and brain tryptophan metabolism. Nature. 1972; 239(5373): 452-453, doi: 10.1038/239452a0, indexed in Pubmed: 4562870.

35. Madras BK, Cohen EL, Fernstrom JD, et al. Letter: Dietary carbohydrate increases brain tryptophan and decreases free plasma tryptophan. Nature. 1973; 244(5410): 34-35, doi: 10.1038/244034a0, indexed in Pubmed: 4582482.

36. Felig P, Kim YJ, Lynch V, et al. Amino acid metabolism during starvation in human pregnancy. J Clin Invest. 1972; 51(5): 1195-1202, doi: 10.1172/JCI106913, indexed in Pubmed: 5020432.

37. Kalhan SC. Protein metabolism in pregnancy. In: Cowett R.M. ed., Principles of Perinatal-Neonatal Metabolism. 2nd ed. Springer-Verlag, New York 1998: 207-220.

38. Kalhan SC, Gruca LL, Parimi PS, et al. Serine metabolism in human pregnancy. Am J Physiol Endocrinol Metab. 2003; 284(4): E733E740, doi: 10.1152/ajpendo.00167.2002, indexed in Pubmed: 12488240.

39. Metzger BE, Agnoli FS, Freinkel N. Effect of sex and pregnancy on formation of urea and ammonia during gluconeogenesis in the perfused rat liver. Horm Metab Res. 1970; 2(6): 367-368, doi: 10.1055/s-0028-1096820, indexed in Pubmed: 5521648 .

40. Metzger BE, Unger RH, Freinkel N. Carbohydrate metabolism in pregnancy. XIV. Relationships between circulating glucagon, insulin, glucose and amino acids in response to a "mixed meal" in late pregnancy. Metabolism. 1977; 26(2): 151-156, doi: 10.1016/00260495(77)90050-6, indexed in Pubmed: 834148.

41. Phelps RL, Metzger BE, Freinkel N. Carbohydrate metabolism in pregnancy. XVII. Diurnal profiles of plasma glucose, insulin, free fatty acids, triglycerides, cholesterol, and individual amino acids in late normal pregnancy. Am J Obstet Gynecol. 1981; 140(7): 730-736, doi: 10.1097/00132582-198112000-00002, indexed in Pubmed: 7020420.

42. Mustafa R, Ahmed S, Gupta A, et al. A comprehensive review of hypertension in pregnancy. J Pregnancy. 2012; 2012: 105918, doi: 10.1155/2012/105918, indexed in Pubmed: 22685661.
43. Cade JR, Fregly MJ, Privette M. Effect of tryptophan and 5-hydroxytryptophan on the blood pressure of patients with mild to moderate hypertension. Amino Acids. 1992; 2(1-2): 133-142, doi: $10.1007 /$ BF00806084, indexed in Pubmed: 24194281.

44. Feltkamp H, Meurer KA, Godehardt E. Tryptophan-induced lowering of blood pressure and changes of serotonin uptake by platelets in patients with essential hypertension. Klin Wochenschr. 1984; 62(23): 1115-1119, doi: 10.1007/bf01782468, indexed in Pubmed: 6521359.

45. Shirakawa $H$, Inagawa $Y$, Koseki $T$, et al. Regulation of blood pressure and glucose metabolism induced by L-tryptophan in stroke-prone spontaneously hypertensive rats. Nutr Metab (Lond). 2011; 8(1): 45, doi: 10.1186/1743-7075-8-45, indexed in Pubmed: 21831334.

46. Mateos SS, Sánchez CL, Paredes SD, et al. Circadian levels of serotonin in plasma and brain after oral administration of tryptophan in rats. Basic Clin Pharmacol Toxicol. 2009; 104(1): 52-59, doi: 10.1111/j.1742-7843.2008.00333.x, indexed in Pubmed: 19152552.

47. GADDUM JH, HAMEED KA. Drugs which antagonize 5-hydroxytryptamine. Br J Pharmacol Chemother. 1954; 9(2): 240-248, doi: 10.1111/j.1476-5381.1954.tb00848.x, indexed in Pubmed: 13172437.

48. Koren-Schwartzer N, Chen-Zion M, Ben-Porat H, et al. Serotonin-induced decrease in brain ATP, stimulation of brain anaerobic glycolysis and elevation of plasma hemoglobin; the protective action of calmodulin antagonists. Gen Pharmacol. 1994; 25(6): 1257-1262, doi: 10.1016/0306-3623(94)90147-3, indexed in Pubmed: 7875554

49. Mohammad-Zadeh LF, Moses L, Gwaltney-Brant SM. Serotonin: a review. J Vet Pharmacol Ther. 2008; 31(3): 187-199, doi: 10.1111/j.1365-2885.2008.00944.x, indexed in Pubmed: 18471139

50. MacLean MR, Dempsie Y. Serotonin and pulmonary hypertension--from bench to bedside? Curr Opin Pharmacol. 2009; 9(3): 281-286, doi: 10.1016/j.coph.2009.02.005, indexed in Pubmed: 19286424.

51. Maclean MR, Dempsie Y. The serotonin hypothesis of pulmonary hypertension revisited. Adv Exp Med Biol. 2010; 661: 309-322, doi: 10.1007/978-1-60761-500-2_20, indexed in Pubmed: 20204739.

52. Weinstock M, Blotnick S, Segal M. Seasonal variation in the development of stress-induced systolic hypertension in the rat. J Hypertens Suppl. 1985; 3(3): S107-S109, indexed in Pubmed: 2856682.

53. Brent RL. The effect of embryonic and fetal exposure to $x$-ray, microwaves, and ultrasound: counseling the pregnant and nonpregnant patient about these risks. Semin Oncol. 1989; 16(5): 347-368, indexed in Pubmed: 2678486.

54. Barnett SB, Maulik D, Barnett SB, et al. International Perinatal Doppler Society. International recommendations and guidelines for the safe use of diagnostic ultrasound in medicine. Ultrasound Med Biol. 2000; 26(3):355-366, doi: 10.1016/s0301-5629(00)00204-0, indexed in Pubmed: 10773365.

55. Mendelson MA. Cardiac disease and cardiac surgery in pregnant. In: Wenger N.K., Collins P. eds., Women and heart disease, 2nd ed. Taylor and Francis, London and New York 2005: 303-319.

56. Glenmullen J. Prozac Backlash: Overcoming the Dangers of Prozac, Zoloft, Paxil, and Other Antidepressants With Safe, Effective Alternatives. Simon \& Schuster, New York 2001. 